\title{
Case report and review of literature: incisional site metastasis in patient with carcinoma cervix
}

\author{
Sangeeta Gupta ${ }^{1}$, Taru Gupta ${ }^{1}$, Parminder Kaur ${ }^{1} *$, Manish Jain ${ }^{2}$
}

\author{
${ }^{1}$ Department of Obstetrics and Gynaecology, ESI PGIMSR, Basaidarapur, New Delhi, India \\ ${ }^{2}$ Department of Surgery, ESI PGIMSR, Basaidarapur, New Delhi, India
}

Received: 14 September 2016

Accepted: 08 October 2016

\author{
* Correspondence: \\ Dr. Parminder Kaur, \\ E-mail: saggi.paro@gmail.com
}

Copyright: (C) the author(s), publisher and licensee Medip Academy. This is an open-access article distributed under the terms of the Creative Commons Attribution Non-Commercial License, which permits unrestricted non-commercial use, distribution, and reproduction in any medium, provided the original work is properly cited.

\begin{abstract}
Metastasis to skin occurs rarely in gynaecological malignancies especially in carcinoma cervix. Cervical malignancy mainly metastasizes to the pelvis, lungs, bones, and liver. Metastasis to the skin is an unusual presentation during the course of carcinoma of the cervix, even in terminal stages of disease. The prognosis after skin metastasis is poor and often a terminal presentation. We report a case of a patient who underwent total abdominal hysterectomy with bilateral salpingo-oophorectomy for postmenopausal bleeding without preoperative evaluation in a private enterprise in 2012 and carcinoma cervix (squamous cell carcinoma) was detected on histopathology. For the same, she received chemoradiation at an Oncocentre. Twenty two months after surgery she developed recurrence on abdominal scar site. At PGIMSR Basaidarapur she underwent wide local excision of anterior abdominal wall with tensor fascia lata flap elevation. Presently she is under follow-up and planned for chemotherapy. To conclude, incisional cutaneous metastasis is a rarity with carcinoma cervix and is considered as an ominous prognostic sign with short survival after diagnosis.
\end{abstract}

Keywords: Carcinoma cervix, Metastasis, Radical hysterectomy

\section{INTRODUCTION}

Squamous cell carcinoma of cervix frequently metastasizes to pelvic lymph nodes. Distant metastasis is rare and usually observed in lung, liver and bone. Metastatic carcinoma to the skin is an uncommon occurrence, with incidence rate of $0.1-2 \% .^{1,2}$ Incidence of skin metastasis is $0.8 \%$ in stage I, $1.2 \%$ in stage II, $1.2 \%$ in stage III, $4.8 \%$ in stage IV. The incidence of cutaneous metastases in squamous cell carcinoma is $0.9 \%$ and adenocarcinoma $5.8 \% .^{2}$ Incisional site skin metastasis is further rare with incidence of $0.1-1.3 \%$ among the cutaneous metastasis. ${ }^{3}$ Most common sites of skin metastasis reported are abdominal wall, vulva and chest wall. ${ }^{2}$ Till date 42 cases have been reported including incisional, drain and port site metastasis. Out of these 33 were cases of squamous cell carcinoma, 8 adenocarcinoma, and 1 adenosquamous carcinoma. Mean interval between the diagnosis of cervical cancer and skin metastasis reported is 14 months (range 0-69 months). Carlson et al reported occurrence of metastatic carcinoma to skin in 26 out of a study group of 2220 patients. They noted that with modern radiotherapy, cancer control in the pelvis is improved, and distant metastasis would become more clinically evident. ${ }^{4}$

\section{CASE REPORT}

Sixty years old female $\mathrm{P}_{4} \mathrm{~L}_{4}$ had an episode of postmenopausal bleeding in January 2012 for which she underwent total abdominal hysterectomy with bilateral salpingo-oophorectomy at private hospital within a week of presentation. Patient reported to ESI Basaidarapur Delhi in March 2012 with histopathology report showing squamous cell carcinoma of cervix. No abnormality was detected in general physical examination, blood and radiological investigations. Ultrasound and CT scan (whole abdomen and pelvis) showed no mass, no 
lymphadenopathy or free fluid. Case was discussed with Oncologist and patient received 6 cycles of chemoradiation (cisplatin + external beam radiotherapy) in view of incomplete primary surgery. Patient was kept under follow up and annual vault smear, USG abdomen and Chest $\mathrm{X}$ ray were done. Twenty two months later, she noticed $\approx 1 \mathrm{~cm}$ painless, fluctuant nodule on abdominal scar area. She presented in August 2014 with a multinodular swelling grown over a period of 8 months. On local examination, there was an infra umbilical nontender swelling of $8 \times 10 \mathrm{~cm}$ on scar site with multiple sinuses over it draining purulent discharge (Figure 1).

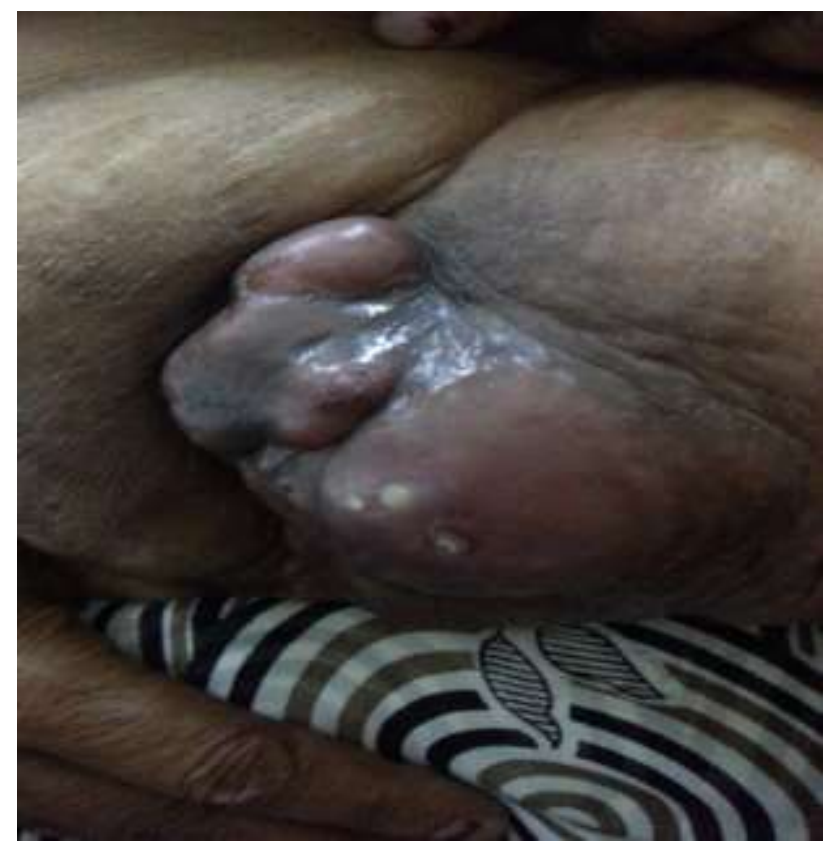

Figure 1: Infraumbilical multinodular swelling on abdominal skin.

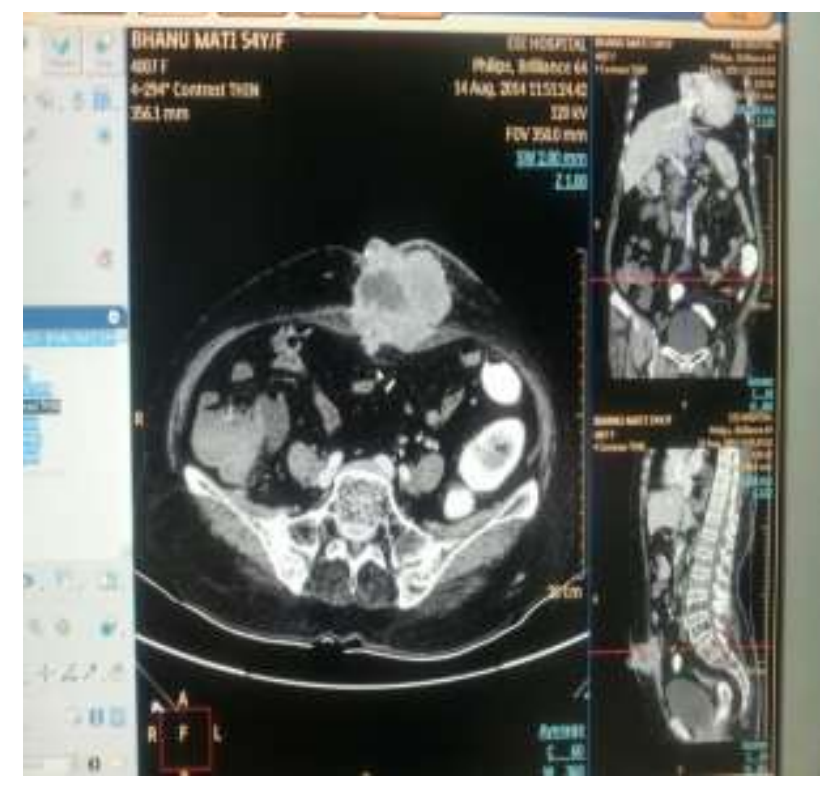

Figure 2: CT scan film showing mass in anterior abdominal wall.
CT Scan (Aug 2014) showed $8.1 \times 7.3 \times 6.1 \mathrm{~cm}$ heterogeneously enhancing soft tissue with areas of necrosis in anterior abdominal wall involving skin, subcutaneous tissue, bilateral rectus abdominis muscle with intrabdominal extension of mass involving adjacent part of omentum, no lymphadenopathy, no free fluid, no bowel involvement. No evidence of metastasis elsewhere (Figure 2).

FNAC from the lump showed squamous cell carcinoma. Patient and relatives were counselled about the cutaneous metastasis of cervical cancer and treatment options. Wide local excision $15 \times 15 \mathrm{~cm}$ of anterior abdominal wall including $2 \mathrm{~cm}$ of healthy margin along with infracolic omentectomy was done in sep 2014. Tensor fascia lata musculocutaneous flap elevated to cover the defect (Figure 3).

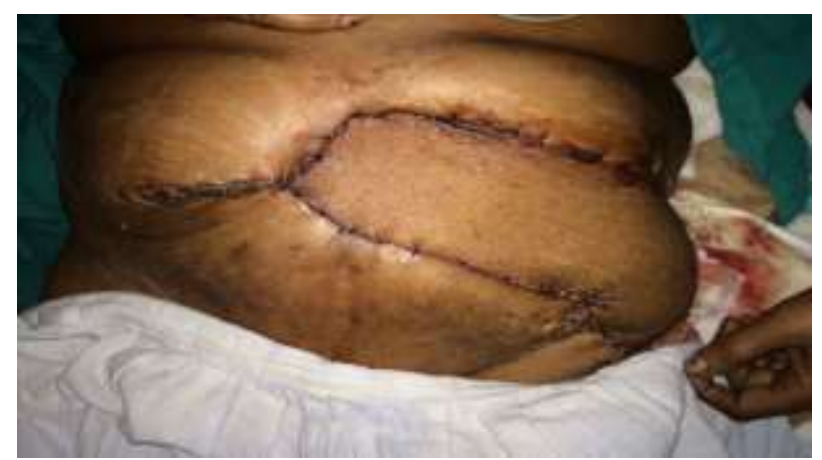

Figure 3: Wide local excision, defect covered with tensor fascia lata musculocutaneous flap.

Histopathology of the resected lesion showed squamous cell carcinoma with extensive necrosis, lymphovascular invasion and deep resected margins and skin margins were free. Wound healing took almost one month. Repeat CECT in May 2015 showed abdominal wall defect on left side with hernaition of bowel loops, bilateral external iliac lynphadenopathy. FNAC from left external iliac lymph node reported as squamous cell carcinoma. She received Image guided radiotherapy (IGRT based external beam RT) using $6 \mathrm{MV}$ photon beam on Clinac iX (LINAC) to a dose of $45 \mathrm{~Gy}$ in 25 fractions to residual disease and inguinal lymph nodes with concurrent weekly cisplatin chemotherapy.

November 2015, she presented with multiple nodular lesions on right gluteal area. Same nodules were biopsied and showed metastatic squamous cell carcinoma. PETCT depicts mediastinal and right inguinal lymphadenopathy with lesions in liver likely metastatic. Then she was treated with paclitaxel carboplatin chemotherapy regime. Presently patient is alive and under follow up.

\section{DISCUSSION}

Although incisional site recurrences have been documented in the form of anecdotal reports in the 
literature, it has never found a place in the list of recognized surgical complications. Owing to rarity of such cases there have been no large series reported in literature.

Table 1: Reported cases of Incisional Site Metastasis of Cervical Carcinoma.5,9,13-15

\begin{tabular}{|c|c|c|c|c|c|c|c|}
\hline $\begin{array}{l}\text { Year/Age } \\
\text { Author }\end{array}$ & Stage & $\begin{array}{l}\text { Type of } \\
\text { surgery }\end{array}$ & $\begin{array}{l}\text { Type } \\
\text { Histo }\end{array}$ & $\begin{array}{l}\text { Postop } \\
\text { radiotherapy }(\mathrm{RT})\end{array}$ & $\begin{array}{l}\text { Time of } \\
\text { recurrence }\end{array}$ & Treatment & Survival \\
\hline $\begin{array}{l}63 \text { yrs, } \\
\text { Liro et al }\end{array}$ & II A & $\begin{array}{l}\text { Radical } \\
\text { Hysterectomy }\end{array}$ & $\mathrm{SCC}$ & Yes & 6 months & $\begin{array}{l}\text { Wide excision + } \\
\text { Chemotherapy }\end{array}$ & 3 months \\
\hline $\begin{array}{l}35 \text { yrs, } \\
\text { Srivastava } \\
\text { et al }\end{array}$ & II A & $\begin{array}{l}\text { Radical } \\
\text { Hysterectomy }\end{array}$ & $\mathrm{SCC}$ & Yes & 3.5 years & $\begin{array}{l}\text { Wide excision }+ \\
\text { Chemotherapy }\end{array}$ & Few months \\
\hline $\begin{array}{l}\text { Sachdev et } \\
\text { al }\end{array}$ & - & $\begin{array}{l}\text { Radical } \\
\text { Hysterectomy }\end{array}$ & SCC & No & - & Surgery & - \\
\hline $\begin{array}{l}45 \text { yrs, } \\
\text { Ding et al }\end{array}$ & I B & $\begin{array}{l}\text { Radical } \\
\text { Hysterectomy }\end{array}$ & SCC & No & 2.5 years & $\begin{array}{l}\text { Wide excision + } \\
\text { Chemotherapy }\end{array}$ & - \\
\hline $\begin{array}{l}2 \text { cases, } \\
\text { Deka et al }\end{array}$ & - & $\begin{array}{l}\text { Radical } \\
\text { Hysterectomy }\end{array}$ & SCC & - & - & Wide excision & - \\
\hline $\begin{array}{l}52 \text { yrs, } \\
\text { Sugam et al }\end{array}$ & I B & $\begin{array}{l}\text { Radical } \\
\text { Hysterectomy }\end{array}$ & $\mathrm{SCC}$ & No & 3 months & Chemotherapy & 3 months \\
\hline $\begin{array}{l}45 \text { yrs, } \\
\text { Singh et al }\end{array}$ & - & $\begin{array}{l}\text { Simple } \\
\text { Hysterectomy }\end{array}$ & SCC & No & 6 months & RT & - \\
\hline $\begin{array}{l}31 \text { yrs, } \\
\text { Selo-Ojeme } \\
\text { et al }\end{array}$ & I A & $\begin{array}{l}\text { Radical } \\
\text { Hysterectomy }\end{array}$ & Adeno & No & 5 years & Wide excision & - \\
\hline $\begin{array}{l}\text { Iavazzo et } \\
\text { al }\end{array}$ & I B 1 & $\begin{array}{l}\text { Radical } \\
\text { Hysterectomy }\end{array}$ & Adeno & No & 3 years & $\begin{array}{l}\text { Wide excision }+ \\
\text { Chemotherapy }\end{array}$ & $>6$ months \\
\hline $\begin{array}{l}46 \text { yrs, } \\
\text { RSCH }\end{array}$ & I B 1 & $\begin{array}{l}\text { Radical } \\
\text { Hysterectomy }\end{array}$ & Adeno & No & 3 years & $\begin{array}{l}\text { Wide excision + } \\
\text { Chemotherapy }\end{array}$ & - \\
\hline Sil et al & - & $\begin{array}{l}\text { Simple } \\
\text { Hysterectomy }\end{array}$ & Adeno & No & 4 months & $\begin{array}{l}\text { Wide excision }+ \\
\text { Chemoradiation }\end{array}$ & $\begin{array}{l}\text { Well at } 5 \\
\text { months }\end{array}$ \\
\hline $\begin{array}{l}60 \text { yra } \\
\text { Sangeeta et } \\
\text { al }\end{array}$ & - & $\begin{array}{l}\text { Simple } \\
\text { Hysterectomy }\end{array}$ & $\mathrm{SCC}$ & Yes, CTRT & 22 months & $\begin{array}{l}\text { Wide excision + } \\
\text { Chemotherapy }\end{array}$ & $\begin{array}{l}\text { Under follow } \\
\text { up }\end{array}$ \\
\hline
\end{tabular}

The actual incidence of incisional site metastasis might be higher than identified in this paper due to lack of reporting them. There are 42 case reports of incisional, drain and port site metastasis. Thirty-three, eight, and one were squamous, adeno and adenosquamous carcinomas, respectively. Wide excision was performed in 30/37 cases of which we have information regarding the treatment option, while 11/37 and 13/37 underwent radiotherapy and chemotherapy, respectively. ${ }^{2,} 5$ Incisional site metastasis is commonly seen in adenocarcinoma of abdominal and pelvic organ malignancies but in case of carcinoma cervix, it is seen more common in squamous cell carcinoma as compared to adenocarcinoma.

Median time of recurrence is 14 months (range 1.545 months). Risk factors include local immunoreactions, wound hypoxia, acidosis leading to angiogenesis and haematogenous spread, stage and type of carcinoma and surgical technique.

Macroscopically 3 common patterns of skin metastasis such as nodules, plaques and inflammatory telangiectatic lesions have been recognized. ${ }^{6}$ In this case metastatic lesion developed as nodule and later turned into an ulceroproliferative lesion.

There are two possible mechanisms that could explain the development of metastatic recurrence in a surgical wound. First, it is possible for direct tumor seeding to occur at the time of surgery. Secondly, circulating tumor cells may become trapped by fibrin platelet deposits in the microcirculation of the wound. Copas et $\mathrm{al}^{7}$ and Behtash et $\mathrm{al}^{8}$ reported cases of carcinoma cervix where retroperitoneal drain was placed through separate incision after radical hysterectomy and patient developed drain site metastasis later on. Laparoscopic procedures are used infrequently in cervical carcinoma. Port site metastasis after laparoscopic lymphadenectomy is a new phenomenon.

In present case, time of recurrence was 22 months following simple hysterectomy done for benign cause and malignancy was detected on histopathology report; similar case was reported by Singh et al in 2012 with 
recurrence time of 6 months and treated with radiotherapy. ${ }^{9}$ Others cases had underwent complete radical surgery for known case of carcinoma cervix, with recurrence time of 12 months. Most of them were treated with wide local excision followed by chemotherapy. In this case patient was treated with wide local excision showing negative margins on histopathology and defect was repaired with tensor fascia lata flap. Patient was discharged with a plan of chemotherapy.

No strict guidelines regarding treatment are available in literature owing to scanty number of cases reported. The management of these patients depends largely upon disease extent. Distant metastasis in organs such as lung, liver and bone render these patients unsuitable for curative treatment. Biopsy is necessary to prove the origin of the metastasis. Careful and close follow up including examination and imaging with special attention to incision, port, or drain sites is proposed to early identify such a recurrence. Treatment of such recurrences remains palliative and includes chemotherapy, radiotherapy or wide surgical excision. After wide local excision reconstruction of the abdominal wall with a latissimus dorsi musculocutaneous flap as well as mesh use are proposed in the literature. ${ }^{10}$ Platin-based chemotherapy is usually recommended, though fluorouracil or topotecan have also been used. Although treatment should be individualized, it seems that wide excision in combination with chemotherapy could be the best treatment option.

Prognosis associated with cutaneous metastasis of cervical carcinoma is poor. The mean survival of patients is 3 months. ${ }^{1,11}$ In this case, patient is alive and under regular follow up. It is difficult to clarify the prognosis of such a recurrence. Ramirez et al showed that in a median follow-up period of 12 months, $63 \%$ of patients died of disease. $^{12}$

\section{CONCLUSION}

Cutaneous metastasis in a patient with carcinoma cervix is a rare entity; however follow-up and treatment should be further clarified. During follow-up, a close attention should to incision, port, or drain sites are proposed to early identify such a recurrence. A multicentric analysis should be proposed in order to clarify the prevention and management of such cases.

Funding: No funding sources Conflict of interest: None declared

Ethical approval: Not required

\section{REFERENCES}

1. Brady LW, O Neil EA, Farber SH. Unusual sites of metastasis. Semin Oncol. 1977;4:59-64.

2. Imachi M, Tsukamoto N, Kinoshita S, Nakano H. Skin metastasis from carcinoma of uterine cervix. Gynecol Oncol. 1993;48:349-54.

3. Greenlee RM, Chervenak FA, Tovell MMH. Incisional recurrence of a cervical carcinoma - report of a case. JAMA. 1981;246:69-70.

4. Carlson V, Delclos L, Fletcher GH. Distant metastasis in squamous cell carcinoma of uterine cervix. Radiology. 1967;88:961-6.

5. Verma S, Kaur T, Verma R, Dhawan S. Scar site metastasis in cervical carcinoma - A rare case report and Review of Literature. J K Science. 2013;15(1):41-4.

6. Brownstein MH, Helwig EB. Patterns of cutaneous metastasis. Arch Dermatol. 1972;105:862-8.

7. Copas PR, Spann CO, Thomas WW. Squamous cell carcinoma of the cervix metastatic to a drain site. Gynecol Oncol. 1995;56:102-04.

8. Behtash N, Ghaemmaghani F, Yarandi F, et al. Cutaneous metastasis from carcinoma cervix at the drain site: a case report. Gynaecol oncol. 2002;85:209-11.

9. Singh S, Kaur A, Kaur V, Jain A. Implantation tumors at surgical incision scars. JIMSA. 2012;25(2).

10. Neven P, Shepherd JH, Tham KF, Fisher C, Breach $\mathrm{N}$. Reconstruction of the abdominal wall with a latissimus dorsi musculocutaneous flap: a case of a massive abdominal wall metastasis from a cervical cancer requiring palliative resection. Gynecologic Oncology. 1993;49:403-06.

11. Picone O, Aucouturier JS, Louboutin A, Coscas Y, Camus E. Abdominal wall metastasis of cervical adenocarcinoma at laparoscopic trocar insertion site after ovarian transposition: case report and review of the literature. Gynecol Oncol. 2003;90:446-9.

12. Ramirez PR, Frumovitz M, Wolf JK, Levenback C. Laparoscopic port-site metastases in patients with gynaecological malignancies. Int $\mathrm{J}$ Gynecological Cancer. 2004;14(6):1070-7.

13. Basu B, Mukherjee S. Cutaneous metastasis in cancer of the uterine cervix: A case report and review of the literature. J Turkish German Assoc 2013;14:174-7.

14. Iavazzo C, Madhuri K. Incisional Site Metastasis in apatient with cervical carcinoma: A case report and review of literature. Case Reports in Obstetrics and Gynecology. 2012.

15. Sil AK, Biswas B, Saha JK, Datta M, Mondol SK, Ghosh A. Indian Med Assoc. 2012;110(9):649-50.

Cite this article as: Gupta S, Gupta T, Kaur P, Jain M. Case report and review of literature: incisional site metastasis in patient with carcinoma cervix. Int $\mathbf{J}$ Reprod Contracept Obstet Gynecol 2016;5:4052-5. 